\title{
A Case Study On Golden Hope Plantations Berhad
}

\author{
Ahmad Ibn Ibrahimy \\ Faculty of Economics and Business, Universiti Malaysia Sarawak (UNIMAS)
}

\begin{abstract}
In order to provide a better understanding of various aspects of plantations industry in Malaysia, this case study is undertaken on Golden Hope Plantations Berhad. Using SWOT analysis, some fundamental strategies are suggested helping Golden Hope sustain in difficult times and to strengthen and transform it over time. To conclude, Golden Hope is a technologically failure company.
\end{abstract}

Key words: Malaysia, Plantation industry, SWOT Analysis

\section{INTRODUCTION}

Golden Hope Plantations Berhad was acquired by Sime Darby Berhad on 27 November, 2007. Its core business areas in agribusiness, property development, resource based manufacturing and international operations. But agribusiness facilitated the key contributions to its earnings. while the property sector responded well to the fair market conditions and prevailing strategic opportunities. It was operating in Bangladesh, Indonesia, Vietnam, China, Germany, Netherlands and in origin country Malaysia. Golden Hope rationalized its management structure and reduced the production cost by minimal chemical usage with efficient zero-burning policy. Despite the increase in production, the return of oil per hectare did not reflect the technological and scientific advantages made. It was very important to the company as it revealed a low level of output and production-cost had increased drastically. As a result, these issues made the company less competitive.

\section{SWOT ANALYSIS}

The process of strategic management starts from corporate diagnosis. The corporate diagnosis usually begins with SWOT (Strengths, Weaknesses, Opportunities and Threats) analysis. The SWOT analysis is to be interpreted by means of diagnosing the specific problems of the organization. A company performs its functions within the environmental forces, social, economic, political/legal and technological. Some of these forces are external, variable and generally not controlled by the top management. Other forces are internal to a company and thus are essentially controllable by the top management. For internal environment, strength is in the case of a favorable factor or weakness is in the case of an unfavorable factor and both factors are controllable in nature. These factors exist within an organization. They are also advantageous strategic factors of a firm. Identifying strengths is important because future performance can be built on such strengths. Strengths of an organization are not always permanent factors. Hence, a need arises to forge a conscious effort for identifying and evaluating them. Weaknesses, on the other hand, are limiting factors which prevent the organization from realizing its potential. They indicate areas which call for improvement. Since many of the major weaknesses of an organization can be traced to the policies of top management group, one often notices a degree of reluctance by top management to probe failures. Hence, a sincere attempt should be made to convert weaknesses into strengths. For external environment, opportunity is in the case of favorable factor or threat is in the case of unfavorable factor and both are uncontrollable factors that exist in an organization's environment. Opportunities denote those environmental conditions which are expected to have favorable and positive impact on the organization. Threats represent the forces in the external environmental conditions which might have negative, adverse, unfavorable consequences for the organization - its objective, policies, strategies and performance. 


\section{STRATEGY IMPLEMENTATION}

Strategy implementation is the processes to deliver the company's strategy and performance that has to be sustainable against change and volatility. Based on the TWOS matrix of this study, Golden Hope needed turning strategic goals program to compete. The management should delegate the task of developing these plans to multifunctional teams called program teams. The same teams will carry out the turning strategic goals program when they are approved. Pay increase, bonuses and promotion can be incentives of individual performance if they were successfully managed. Golden Hope could offer specific monetary and psychological rewards for accomplishing measurable strategic change tasks and for exhibiting the values and behaviors with which the entire organizations should aligned. The company should recognize where to invest and to whom the resources should be allocated in dealing with all the strategies to be implemented. For implementing these aspects, Golden Hope had to differentiate the usual processes and its core processes. Core processes deal with delivering the superior goods and services that give Golden Hope a competitive advantage. They provide the cost structure that makes the company profitable. Suggested core processes would be like new product development, customer service and information system. In order to remain as a market leader, Golden Hope must not only yield outputs faster and cheaper than its competitor but those outputs must perform better and be of higher quality. By reengineering the core processes, the company should have been able to improve profitability significantly and these core businesses must be continuously improved to keep its performance ahead of the competition.

\section{CONCLUSION}

Based on Golden Hope's external and internal environment, the following strategies were strongly advisable to be implemented. From the process of strategy formulation, the most preferred strategies are: (i) Backward Integration; (ii) Cost Leadership; (iii) Market Penetration; (iv) Product Development and (v) Market Development. The strategy implementation should have been design to suit these strategies in order to get maximum benefits. Golden Hope was stable and was expected to last for a long time provided that it maintains competitive advantages of core competencies and capitalizes on its enormous sales to generate more sales and profit. It was believed that Golden Hope should prevail in the coming stiffer competition. Despite low prices, plantations should stay with adequate agronomic contributions to safeguard earnings by using proper technologies.

\section{REFERENCES}

Golden Hope Plantations Berhad. (1997a). The Zero Burning Technique for Oil Palm Cultivation. Kuala Lumpur, Malaysia: Golden Hope Plantations Berhad.

Golden Hope Plantations Berhad. (1997b). Integrated Pest Management in Oil Palms. Kuala Lumpur, Malaysia: Golden Hope Plantations Berhad.

Henson, I. E. (1990). Estimating potential productivity of oil palm. Workshop on Yield Potential of Oil Palm. PORIM, 98-102.

Jalani, B. S. (1998). Oil palm research and development in Malaysia: progress and trends. The Planter, 74(863), 73-92.

Khoo, K.M. (2001). Developing trends in the Malaysian palm oil industry, PIPOC International Palm Oil Congress- Economics and Marketing Conference, MPOB, Bangi.

Lee, C.H. and Toh, P.Y. (1991). Yield performance of Golden Hope OPRS DxP planting materials, The Planter, 67(784), 317-324.

(C) 2018 UNIMAS All Rights Reserved

Page | 141 
Pushparajah, E. (2001). Strategic direction for the sustainability of the oil palm industry. The Planter, 77(904), 389-404.

RSPO (Roundtable on Sustainable Palm Oil). Malaysia sets record as world's largest producer of certified sustainable palm oil. 2011. (July 29, 2013).

Senik, Rosmila and Mat Daud, Zaidi and Mohamed, Zainal Abidin and Zubir, Mohamad Shahnaz (2011). Golden Hope Plantations Berhad: which project to invest? Asian Journal of Case Research, 4(1), $1-18$.

Teoh, C.H. (2002). The business case for sustainable development in the oil palm industry, R \& D for Competitive Edge in the Malaysian Oil Palm Industry, Bangi.

Yin, R. K. (2014). Case Study Research: Design and Methods. ${ }^{\text {th }}$ Edition. Sage Publications.

Corresponding Author: Ahmad Ibn Ibrahimy can be contacted at iahmad@unimas.my 